\title{
Turbidity in the fluvial Gironde Estuary (southwest France) based on 10-year continuous monitoring: sensitivity to hydrological conditions
}

\author{
I. Jalón-Rojas ${ }^{1, *}$, S. Schmidt ${ }^{1}$, and A. Sottolichio ${ }^{1}$ \\ ${ }^{1}$ UMR5805 EPOC, CNRS-Université de Bordeaux, Pessac, France \\ * Invited contribution by I. Jalón-Rojas, recipient of the EGU Outstanding Student Poster Award 2014.
}

Correspondence to: I. Jalón-Rojas (isabel.jalon-rojas@u-bordeaux.fr)

Received: 12 February 2015 - Published in Hydrol. Earth Syst. Sci. Discuss.: 10 March 2015

Accepted: 2 June 2015 - Published: 18 June 2015

\begin{abstract}
Climate change and human activities impact the volume and timing of freshwater input to estuaries. These modifications in fluvial discharges are expected to influence estuarine suspended sediment dynamics, and in particular the turbidity maximum zone (TMZ). Located in southwest France, the Gironde fluvial-estuarine system has an ideal context to address this issue. It is characterized by a very pronounced TMZ, a decrease in mean annual runoff in the last decade, and it is quite unique in having a long-term and highfrequency monitoring of turbidity. The effect of tide and river flow on turbidity in the fluvial estuary is detailed, focusing on dynamics related to changes in hydrological conditions (river floods, periods of low discharge, interannual changes). Turbidity shows hysteresis loops at different timescales: during river floods and over the transitional period between the installation and expulsion of the TMZ. These hysteresis patterns, that reveal the origin of sediment, locally resuspended or transported from the watershed, may be a tool to evaluate the presence of remained mud. Statistics on turbidity data bound the range of river flow that promotes the upstream migration of TMZ in the fluvial stations. Whereas the duration of the low discharge period mainly determines the TMZ persistence, the freshwater volume during high discharge periods explains the TMZ concentration at the following dry period. The evolution of these two hydrological indicators of TMZ persistence and turbidity level since 1960 confirms the effect of discharge decrease on the intensification of the TMZ in tidal rivers; both provide a tool to evaluate future scenarios.
\end{abstract}

\section{Introduction}

Macrotidal estuaries are highly variable systems as a result of the strong influence of both tides and river discharge. In particular, dynamics of suspended particulate matter (SPM) and the occurrence of a turbidity maximum zone (TMZ) are complex and difficult to predict (Fettweis et al., 1998; Mitchell and Uncles, 2013). Different processes can induce the formation of the TMZ (for details see Allen et al., 1980; Dyer, 1988; Jay and Musiak, 1994; Talke et al., 2009). This highly concentrated zone plays an important role in estuarine morphodynamics. Sediment depositions from the TMZ may generate gradual accretion of bed and banks (Pontee et al., 2004; Schrottke et al., 2006; Uncles et al., 2006). Therefore, many estuaries require regular dredging against ongoing siltation events to maintain the depth of navigation channels.

Quite recently, considerable attention has been paid to evaluate the effect of climate change (Fettweis et al., 2012) and human interventions (Schuttelaars et al., 2013; Winterwerp and Wang, 2013; Yang et al., 2013; De-Jonge et al., 2014) on natural distribution of SPM in estuaries. There is numerical evidence linking freshwater abstractions to an increased potential for up-estuary transport (Uncles et al., 2013). Nevertheless the effects of shifts in freshwater inflow on sediment regime are not yet fully understood (Mitchell and Uncles, 2013). The longitudinal TMZ migration as a result of seasonal variability of runoff has been well described in many estuaries (Grabemann et al., 1997; Uncles et al., 1998; Guézennec et al., 1999). However, the effect of floods or long-term hydrological variability on sediment dynamics is scarcely documented - Grabemann and Krause (2001) 
showed differences in SPM concentrations of the TMZ in the Weser Estuary between a dry and a wet year, although the gaps in data hamper a detailed analysis. The transitional periods of upstream migration and downstream flushing of the TMZ and of its associated mobile mud in fluvial sections have also not been detailed. These limitations are partly due to the absence of relevant long-term data sets, which are not so common in estuaries (Garel et al., 2009; Contreras and Polo, 2012).

The Gironde fluvio-estuarine system (SW France) is unique in having a long-term and high-frequency monitoring of water quality. This estuary presents a pronounced TMZ well documented in the lower and central reaches (Allen and Castaing, 1973; Allen et al., 1980; Sottolichio and Castaing, 1999). The Gironde watershed has the largest water structural deficit in France (Mazzega et al., 2014). Warming climate over the basin induces a decrease in mean annual runoff, a shift to earlier snow melting in mountainous areas and more severe low-flow conditions (Hendrickx and Sauquet, 2013). In addition, according to data of the agricultural census, irrigated areas have duplicated its surface in several regions of the watershed between 1988 and 2000, promoting strong water storage and abstractions. This context makes the Gironde estuary a good example to evaluate how changes in freshwater regime may affect the estuarine particle dynamic.

The goal of this work is to analyse the response of fine sediments to hydrological fluctuations, based on a 10-year high-frequency database of turbidity in the fluvial Gironde estuary, in order to do:

1. document the trends of SPM at all representative timescales, from intratidal to interannual variability;

2. analyse the role of floods on the sedimentary dynamic of the tidal rivers;

3. analyse the influence of hydrological conditions on TMZ features (upstream migration, downstream flushing, concentration, persistence);

4. discuss the effect of the long-term decrease of runoff in the upstream intensification of the TMZ.

\section{The study site}

With a total surface area of $635 \mathrm{~km}^{2}$, the Gironde is a macrotidal fluvial-estuarine system located on the Atlantic coast (southwest France, Fig. 1). The estuary shows a regular funnel shape of $75 \mathrm{~km}$ between the mouth and the junction of the Garonne and the Dordogne rivers. Tidal rivers present a single sinuous channel with weak slopes and narrow sections (about 300, 250 and $200 \mathrm{~m}$ at Bordeaux, Portets and Libourne respectively, Fig. 1). At the Gironde mouth, tides are semidiurnal and the mean neap and spring tidal ranges are respectively 2.5 and $5 \mathrm{~m}$ (Bonneton et al., 2015). The tidal wave propagates up to $180 \mathrm{~km}$ from the estuary mouth. Thereby, the uppermost limits for the dynamic tidal zone are (Fig. 1): La Réole for the Garonne River ( $95 \mathrm{~km}$ from the river confluence), and Pessac for the Dordogne River $(90 \mathrm{~km}$ from the river confluence). As the tide propagates upstream, tidal currents undergo an increasing ebb-flood asymmetry (longer and weaker ebb currents; shorter and stronger flood currents) and the wave is amplified (Allen et al., 1980). The tidal wave reaches its maximum value at about $125 \mathrm{~km}$ from the mouth (Bonneton et al., 2015), before decaying in the fluvial narrow sections.

The tidal asymmetry toward upstream and the subsequent tidal pumping coupled to density residual circulation develop a turbidity maximum zone (TMZ). The high tidal ranges and the great length of the estuary promote a highly turbid TMZ (Uncles et al., 2002). In surface waters of the middle estuary, SPM concentrations range between 0.1 and $10 \mathrm{~g} \mathrm{~L}^{-1}$ according to Sottolichio and Castaing (1999). Estuarine suspended sediments have a dominant terrestrial origin and are mainly composed of clays (45-65\%) and silts (Fontugne and Jounneau, 1987). SPM residence time is between 12 and 24 months, depending on river discharge (Saari et al., 2010). Freshwater inflow moves the TMZ along the estuary axis: during high river flow the TMZ moves down-estuary and vice versa (Castaing and Allen, 1981). There is also a secondary steady TMZ in the middle estuary possibly related to a highly dynamic zone, called the "erosion maximum zone" (Allen et al., 1980; Sottolichio and Castaing, 1999). At slack water, sediment deposition occurs on the river bed and banks. In the channel fluid mud can form elongated patches, with concentrations up to $300 \mathrm{~g} \mathrm{~L}^{-1}$ (Allen, 1971).

In contrast to the middle estuary, the tidal Garonne and Dordogne Rivers are still poorly documented. Measurements over a maximum of 3 days (Romaña 1983; Castaing et al. 2006) and satellite images (Doxaran et al., 2009) revealed the seasonal presence of the TMZ during the summer-autumn period. Brief field observations in September 2010 (Chanson et al, 2011) showed the presence of low consolidated mud deposits upstream of Bordeaux. In the following, and in accordance with Uncles et al. (2006), the term mobile mud is used for these low consolidated mud deposits that are easily erodible, and likely to shift seasonally with the TMZ.

\section{Materials and methods}

\subsection{The multiyear high-frequency monitoring system}

The Gironde estuary counts on an automated continuous monitoring network, called MAGEST (MArel Gironde ESTuary), to address the current and future estuarine water quality. The MAGEST network includes four sites (Fig. 1): Pauillac in the central estuary (52 km from the mouth); Libourne in the Dordogne tidal river (115 km from the mouth); and Bordeaux and Portets in the Garonne tidal river (100 and $140 \mathrm{~km}$ from the mouth respectively). The automated stations 


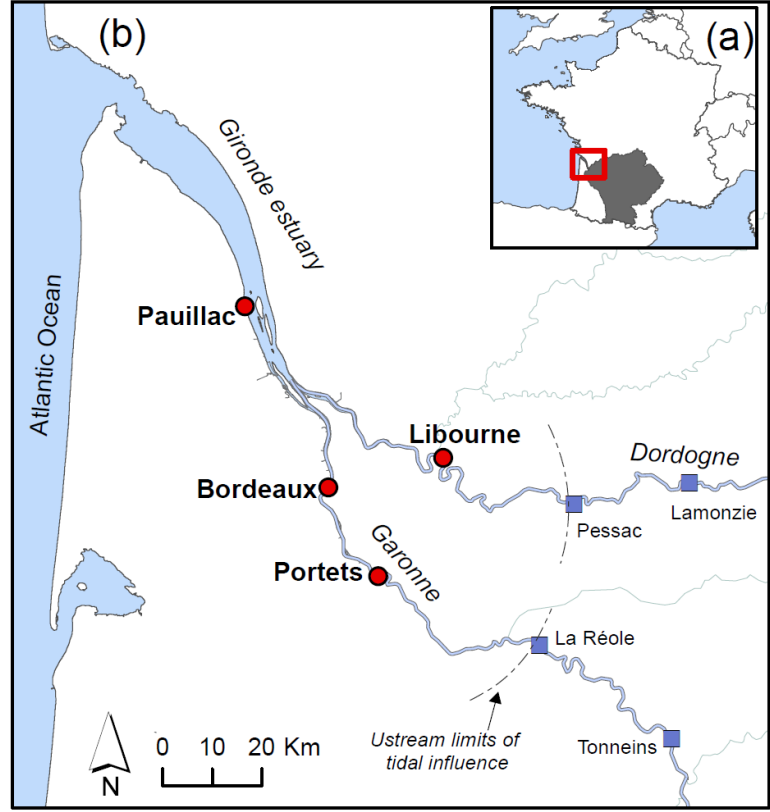

Figure 1. The Gironde fluvial-estuarine system: (a) location map (SW France), the grey area shows the watershed of Garonne and Dordogne; (b) the estuary with its main tributaries. Red circles locate the MAGEST stations; blue squares indicate the hydrometric stations.

record dissolved oxygen, temperature, turbidity and salinity every ten minutes at $1 \mathrm{~m}$ below the surface. In addition, an ultrasonic level controller measures the water depth in the stations of Bordeaux, Portets and Libourne. The turbidity sensor (Endress and Hauser, CUS31-W2A) measures values between 0 and 9999 NTU with a precision of $10 \%$. The saturation value ( $9999 \mathrm{NTU}$ ) of turbidity sensor corresponds to about $6 \mathrm{gL}^{-1}$ (Schmidt et al., 2014). One may refer to Etcheber et al. (2011) for a description of the MAGEST survey programme, for the technical features of monitoring system and for examples of the trends in measured parameters; and to Lanoux et al. (2013) for a detailed analysis of oxygen records.

The first implemented station was Pauillac on 15 June 2004. Acquisition at Portets and Libourne stations began on 16 November 2004 and at Bordeaux station on 1 March 2005. Operation of Portets station was stopped on 11 January 2012. The severe environmental conditions, electrical/mechanical failures and sensor malfunctions could cause missing or wrong data. Therefore the database needed a cleaning for erroneous values in turbidity. For example, 9999 NTU corresponds to saturation values, but also to sensor errors, and these latter need to be removed. A routine in Matlab was developed to retain only turbidity values corresponding to saturation. The validated database of turbidity corresponds to 1223486 data points recorded between 2005 and mid-2014. This corresponds to a rate of correct operating of $71,70,70$ and $57 \%$ for Bordeaux, Portets, Libourne and Pauillac stations respectively.

In addition, two tide gauges, managed by the port of Bordeaux (Grand Port Maritime de Bordeaux), record tide height at Pauillac and Bordeaux every $5 \mathrm{~min}$. Hydrometric stations record every 1 to $24 \mathrm{~h}$ discharges of the Dordogne River (Pessac; Lamonzie Saint Martin) and of the Garonne River (La Réole; Tonneins) (Fig. 1). Data are available on the national website: http://www.hydro.eaufrance.fr/.

\subsection{Data treatment}

Turbidity was analysed as a function of river flow and water height at different timescales. To better identify intertidal trends, we calculated tidal-averaged turbidity with its corresponding tidal range. In order to avoid biased averaged values, we only consider the tidal averages corresponding to at least $70 \%$ of measured values for the considered period of time. Since management directives are often based on daily values, tidal and daily averages were compared. Figure 2 compares both turbidity averages and shows a very good agreement between the two calculations $\left(R^{2}=0.993\right)$. Previous works have defined the TMZ in the Gironde estuary by a SPM concentration $>1 \mathrm{~g} \mathrm{~L}^{-1}$ in surface (Allen et al., 1977; Castaing and Allen, 1981), which corresponds to a turbidity of about 1000 NTU. TMZ installation and expulsion are the terms we use for the transitional periods where turbidity oscillates around 1000 NTU in a given station, during the TMZ upstream and downstream migration (see Fig. 3). River floods are defined by a daily increase of the Garonne discharge higher than $480 \mathrm{~m}^{3} \mathrm{~s}^{-1}$ (percentile 75 of river flow during the study period). A time shift was added to discharge time series for the study of floods, since hydrometric stations are located tens of kilometres upstream of the MAGEST ones. This was estimated based on the velocity of the flood peaks between two hydrometric stations.

We performed statistical analysis on the tidal-averaged data. We compared turbidity values according to stations (Portets, Bordeaux, Libourne and Pauillac), period (months, and tidal range), and their interactions (e.g. station within period), by performing analysis of variance. We used parametric tests ( $t$ test and ANOVA) when data sets or their transforms (like log or cubic root) met the normality and homoscedasticity criteria. Otherwise we used non-parametric tests (Mann-Whitney $U$ and Kruskal-Wallis tests). In the following, we refer to data sets as "significantly different" when these tests on tidal-averaged data were significant at $p<0.5$. These tests were carried out using STATA software (v. 12.1, StataCorp, 2011). 


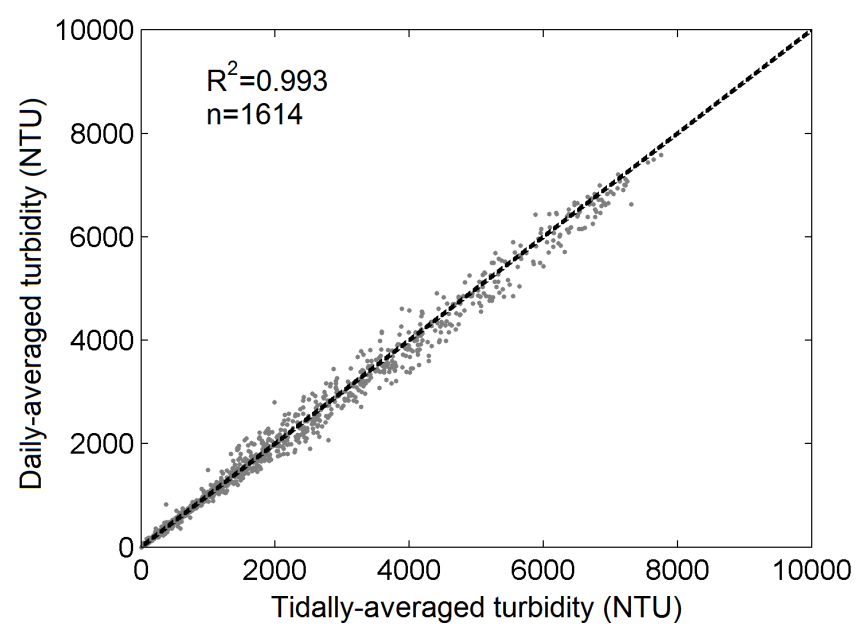

Figure 2. Comparison of tidally averaged turbidity and daily averaged turbidity for Bordeaux station showing the correlation coefficient $\left(R^{2}\right)$.

\section{Results}

\subsection{Hydrological trends}

The Gironde estuary drains a watershed of $81000 \mathrm{~km}^{2}$, (Fig. 1a) strongly regulated by dams and reservoirs. The Garonne and the Dordogne rivers contribute respectively 65 and $35 \%$ of the freshwater input. Historical records reveal drastic changes in hydrological conditions: the annual mean discharge (Garonne + Dordogne) is decreasing, flood events are increasingly scarce and drought periods are becoming more durable. In the period between the 1960s and the 1980s, the mean annual discharge was $1000 \mathrm{~m}^{3} \mathrm{~s}^{-1}$. In contrast, during the studied period (January 2005-July 2014), the mean annual discharge was $680 \mathrm{~m}^{3} \mathrm{~s}^{-1}$ (Fig. 3a). For this period, the interannual variability in freshwater inflow was also remarkable: the driest year was 2011 with a mean discharge of $433 \mathrm{~m}^{3} \mathrm{~s}^{-1}$ and the wetter one was 2013 with a total mean discharge of $961 \mathrm{~m}^{3} \mathrm{~s}^{-1}$. River discharge also varies seasonally, reaching the highest values in January to February and the lowest in August to September. For the studied period, mean discharges were $720 \mathrm{~m}^{3} \mathrm{~s}^{-1}$ in winter (21 December to $20 \mathrm{March}$ ) and $190 \mathrm{~m}^{3} \mathrm{~s}^{-1}$ in summer (21 June to 20 September) for the Garonne River (380 and $105 \mathrm{~m}^{3} \mathrm{~s}^{-1}$ for the Dordogne River).

Tides are semidiurnal (the main harmonic component is the $\mathrm{M}_{2}$ ) with a period of $12 \mathrm{~h} 25 \mathrm{~min}$. Between January 2005 and July 2014, the mean, minimal and maximal values of tidal ranges were respectively about $4.1,1.9$ and $6.1 \mathrm{~m}$ at Pauillac and about 4.9, 2.5 and $6.6 \mathrm{~m}$ at Bordeaux (see the whole time series in Fig. 3b). Spring and neap tides were defined as the tidal cycles for which tidal range is respectively above the 75th percentile (p75) and below the 25 th percentile (p25). These values were about $3.5 \mathrm{~m}(\mathrm{p} 25)$ and $4.7 \mathrm{~m}$ (p75) at Pauillac, and about $4.3 \mathrm{~m} \mathrm{(p25)} \mathrm{and} 5.4 \mathrm{~m}(\mathrm{p} 75)$ at Bordeaux.

\subsection{Short-term variability in turbidity}

Figure 4 presents examples of high-frequency $(10 \mathrm{~min})$ data recorded at Bordeaux under two contrasted conditions of fluvial discharge. Continuous measurements reveal turbidity patterns related to tidal cycles, and to changes in fluvial discharges. Only such a continuous record can capture the turbidity signature of a flood that often occurs for a few hours.

\subsubsection{Tidal cycles}

The first selected data set (Fig. 4, column I) corresponds to a low-water period: the Garonne discharge was below $120 \mathrm{~m}^{3} \mathrm{~s}^{-1}$. Turbidity shows a large range of values between 740 and $9999 \mathrm{NTU}$, testifying to the presence of the TMZ in the tidal river. It is noticeable that turbidity is higher than the saturation value during several hours per tidal cycle. These raw data illustrate the short-term changes in turbidity due to deposition-resuspension processes induced by changes in current velocities throughout the tidal cycles. This pattern was already reported in the central estuary (Allen et al., 1980; Castaing and Allen, 1981). Figure 4c, column I relates turbidity and water level of the raw data, showing more clearly the intratidal patterns: two turbidity peaks due to the resuspension by the maximum current velocities. In contrast minimum turbidity values are always recorded at high tide and low tide due to deposition processes.

\subsubsection{Flood events}

The second selected data set (Fig. 4, column II) represents the turbidity signal related to a spring flood with a discharge peak of the Garonne River at $1730 \mathrm{~m}^{3} \mathrm{~s}^{-1}$. As shown in the middle and lower panels, throughout river floods turbidity is the lowest during rising tide when tidal currents are against river flow; from high tide, river sediments are transported downstream, turbidity values begin to increase and the SPM peak usually occurs between mid-ebbing and low tide. First flood just after low-water periods can present a turbidity peak also at rising tide. These peaks are associated with local resuspension processes and their occurrences are likely to give an indication of the existence of remained mud trapped in the tidal rivers.

Table 1 collects maximum discharge value and its associated maximum turbidity (when recorded) of each flood event at Bordeaux and Portets stations. Flood events are identified in the time series of river discharge in Fig. 3a. The associated turbidity peaks were calculated as the maximum of the turbidity values at low tide (fluvial signature) in order to consider only the sediments transported by river flow. As shown in Table 1 , turbidity maxima during flood events are 5 to 30 times lower compared to TMZ maximum values ( $50 \%$ of the recorded floods present a maximum turbidity < 1000 NTU). 

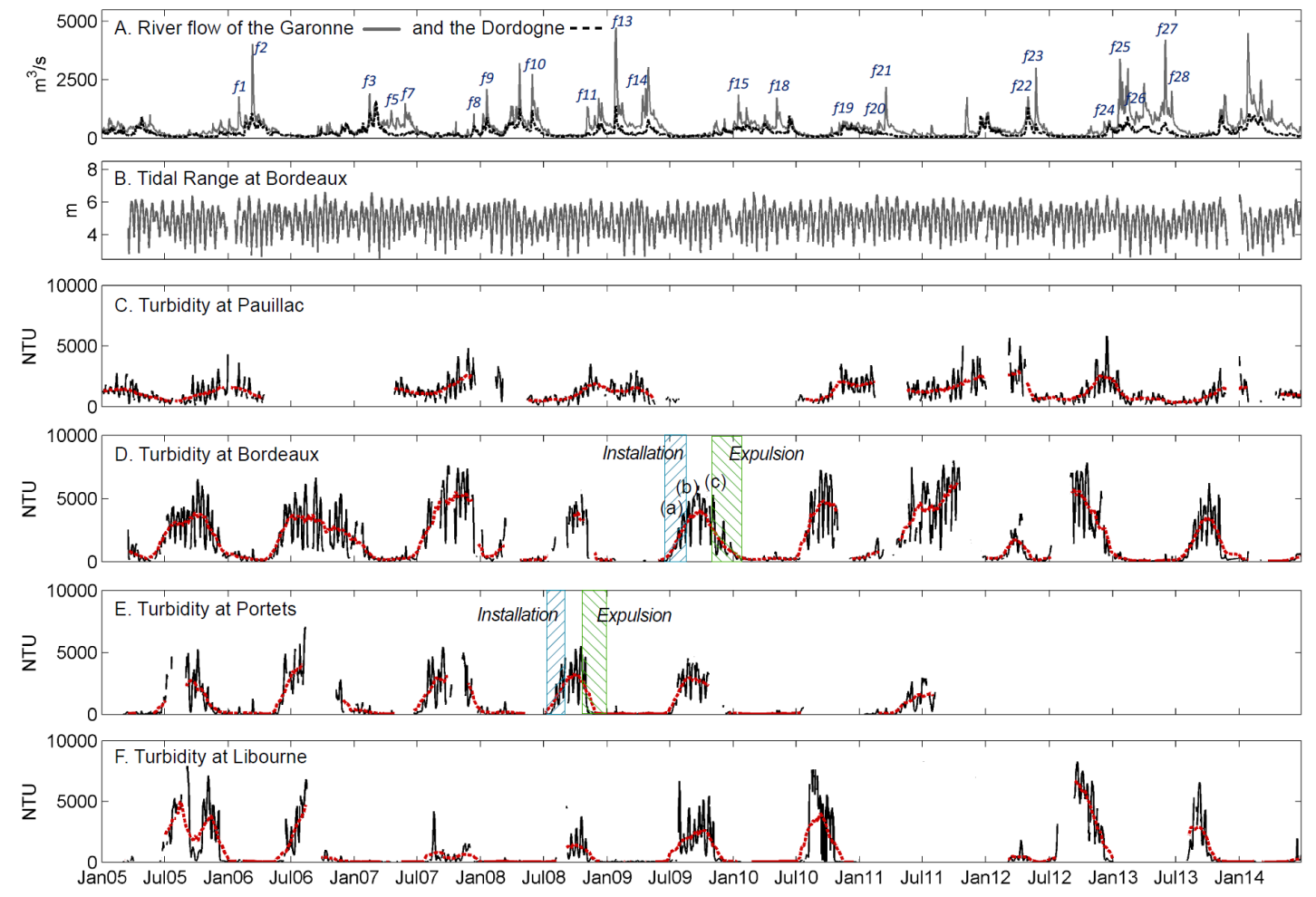

Figure 3. (a) Daily mean flow of the Garonne River and the Dordogne River showing the river flood events of Table 1; (b) tidal range recorded at Bordeaux tide gauge; and tidally averaged turbidity at (c) Pauillac, (d) Bordeaux, (e) Portets and (f) Libourne stations. Red dotted lines represent the low-pass filtered data performed with running averages in order to highlight the turbidity trends. "(f)" plus a number refers to the flood events according to Table 1. "(a)", "(b)" and "(c)" in panel (d) indicate the neap-spring-neap cycles represented in Fig. 10.

\subsection{Long-term variability in turbidity}

\subsubsection{From fortnightly to seasonal variability}

The 10-year time series of tidal averaged turbidity (Fig. 3) reveals short oscillations related to neap-spring tide cycles and seasonal trends induced by hydrology. Maximum turbidity values are recorded during spring tides, since higher current velocities favour the resuspension of sediments (Allen et al., 1980). The highest turbidities occur during low discharge periods (usually between July and November) in the up-estuary waters (Fig. 3d-f) due to the upstream displacement of the TMZ. Turbidity is usually minimal in spring after the flood period. In the middle estuary (Fig. 3c) seasonal changes are more moderate and show an inverse trend. This is due to the existence of a permanent TMZ in this estuarine zone, which is possibly related to a mud-trapping zone (Sottolichio and Castaing, 1999).

Figure 5 summarizes the main characteristics (mean, percentiles) of turbidity to compare the four stations during high (February) and low (August) river discharges and tidal ranges. In the fluvial stations (Bordeaux, Portets, Libourne), turbidity in August is significantly $(p<0.001)$ higher than in February: mean values in August are 8, 27 and 54 times higher than in February at Bordeaux, Portets and Libourne, respectively. By contrast, at Pauillac station, in the central estuary, turbidity remains relatively high throughout the year (see Fig. 3). However, turbidity in August is significantly lower $(p<0.0000001)$ than in February, when TMZ moves upstream. Turbidity values are also significantly different between the three fluvial stations in both dry $(p<0.0018)$ and wet $(p<0.0001)$ months. Summer turbidity values at Bordeaux and Libourne are higher than at Portets and Pauillac, reaching values above 7500 NTU. In February, turbidity is lower in the most upstream stations, with mean tidally averaged turbidity values of 1322, 401, 93 and 52 NTU at Pauillac, Bordeaux, Portets and Libourne, respectively. Turbidity at high tidal range is significantly (e.g. $p<0.000025$ at Pauillac, $p<0.017$ at Libourne) higher than at low tide at all station in August: respectively for Pauillac, Bordeaux, Portets and Libourne, mean turbidity at high tide was 2.7, 2.3, 1.7 and 1.6 times higher compared to low tide. However, in February tidal range does not induce significant differences in turbidity at the most upstream stations of Portets $(p=0.22)$ and Libourne $(p=0.37)$. Only Pauillac and Bordeaux stations present turbidity values significantly higher $(p<0.000001)$ at high tide than at low tide during this month. 
Table 1. Discharge and turbidity characteristics of flood events for the period 2005 to mid-2014 in the tidal Garonne River (Bordeaux and Portets stations). Flood event are numbered by f plus a number according to Fig. 3. Hysteresis loops are classified as: [C] clockwise; [CC] counterclockwise; $[\mathrm{M}]$ mixed; $[\mathrm{No}]$ no trend. Mixed loops with a clear clockwise $[\mathrm{M}(\mathrm{C})]$ or counterclockwise $[\mathrm{M}(\mathrm{CC})]$ predominance are specified. Flood without turbidity record are included to facilitate the interpretation of the hysteresis succession.

\begin{tabular}{|c|c|c|c|c|c|c|}
\hline & \multirow[t]{2}{*}{ Date } & \multirow{2}{*}{$\begin{array}{l}Q_{\max } \\
\left(\mathrm{m}^{3} \mathrm{~s}^{-1}\right)\end{array}$} & \multicolumn{2}{|c|}{ Bordeaux } & \multicolumn{2}{|c|}{ Portets } \\
\hline & & & $T_{\max }(\mathrm{NTU})$ & Hysteresis & $T_{\max }(\mathrm{NTU})$ & Hysteresis \\
\hline \multicolumn{7}{|c|}{2006} \\
\hline & 10 Dec 2005 & 865 & - & - & - & - \\
\hline & 3 Jan 2006 & 938 & - & - & - & - \\
\hline f1 & 31 Jan 2006 & 1820 & 989 & $\mathrm{M}(\mathrm{C})$ & 908 & $\mathrm{CC}$ \\
\hline $\mathrm{f} 2$ & 12 Mar 2006 & 4160 & 1446 & $\mathrm{CC}$ & 1326 & $\mathrm{CC}$ \\
\hline \multicolumn{7}{|c|}{2007} \\
\hline $\mathrm{f} 3$ & 13 Feb 2007 & 2140 & 1460 & $\mathrm{C}$ & 975 & $\mathrm{M}$ \\
\hline $\mathrm{f} 4$ & 27 Feb 2007 & 1600 & 414 & $\mathrm{M}(\mathrm{C})$ & 292 & M \\
\hline f5 & 18 Apr 2007 & 1210 & - & - & 400 & $\mathrm{CC}$ \\
\hline f6 & 3 May 2007 & 953 & 349 & $\mathrm{C}$ & - & - \\
\hline f7 & 28 May 2007 & 1730 & 1794 & $\mathrm{CC}$ & - & - \\
\hline \multicolumn{7}{|c|}{2008} \\
\hline & 11 Dec 2007 & 1270 & - & - & - & - \\
\hline f8 & 8 Jan 2008 & 1120 & 1008 & $\mathrm{C}$ & 313 & M \\
\hline \multirow[t]{2}{*}{ f9 } & 19 Jan 2008 & 2180 & 835 & No & 795 & $\mathrm{CC}$ \\
\hline & 22 Apr 2008 & 3130 & - & - & - & - \\
\hline $\mathrm{f} 10$ & 28 May 2008 & 2640 & 495 & $\mathrm{CC}$ & - & - \\
\hline \multicolumn{7}{|c|}{2009} \\
\hline f11 & 3 Nov 2008 & 1450 & 2200 & $\mathrm{C}$ & 993 & $\mathrm{M}(\mathrm{CC})$ \\
\hline $\mathrm{f} 12$ & 6 Dec 2008 & 1830 & 476 & $\mathrm{CC}$ & - & - \\
\hline f13 & 25 Jan 2009 & 4750 & 1578 & $\mathrm{CC}$ & - & - \\
\hline \multirow[t]{2}{*}{ f14 } & 13 Apr 2009 & 1950 & - & - & 203 & $\mathrm{CC}$ \\
\hline & 30 Apr 2009 & 2870 & - & - & - & - \\
\hline \multicolumn{7}{|c|}{2010} \\
\hline $\mathrm{f} 15$ & 16 Jan 2010 & 1880 & 747 & $\mathrm{M}(\mathrm{CC})$ & - & - \\
\hline f16 & 7 Feb 2010 & 1410 & 358 & No & - & - \\
\hline f17 & 2 Apr 2010 & 1070 & 471 & $\mathrm{M}(\mathrm{C})$ & 152 & No \\
\hline $\mathrm{f} 18$ & 6 May 2010 & 1770 & 971 & $\mathrm{M}(\mathrm{CC})$ & 474 & $\mathrm{CC}$ \\
\hline \multicolumn{7}{|c|}{2011} \\
\hline f19 & 24 Dec 2010 & 1480 & 425 & M & - & - \\
\hline $\mathrm{f} 20$ & 24 Feb 2011 & 1090 & 1598 & M & (C) & 164 \\
\hline $\mathrm{f} 21$ & 18 Mar 2011 & 2150 & - & - & 723 & $\mathrm{CC}$ \\
\hline \multicolumn{7}{|c|}{2012} \\
\hline & 8 Nov 2012 & 1890 & - & - & - & - \\
\hline & 7 Jan 2012 & 1390 & - & - & - & - \\
\hline $\mathrm{f} 22$ & 1 May 2012 & 1760 & 335 & $\mathrm{M}$ & - & - \\
\hline $\mathrm{f} 23$ & 23 May 2012 & 3110 & 963 & $\mathrm{CC}$ & - & - \\
\hline \multicolumn{7}{|c|}{2013} \\
\hline $\mathrm{f} 24$ & 7 Dec 2012 & 834 & 914 & $\mathrm{C}$ & - & - \\
\hline $\mathrm{f} 25$ & 21 Jan 2013 & 3460 & 1075 & $\mathrm{M}$ & - & - \\
\hline \multirow[t]{2}{*}{ f26 } & 9 Mar 2013 & 1150 & 175 & $\mathrm{CC}$ & - & - \\
\hline & 31 Mar 2013 & 2510 & - & - & - & - \\
\hline $\mathrm{f} 27$ & 1 Jun 2013 & 4020 & 768 & $\mathrm{CC}$ & - & - \\
\hline $\mathrm{f} 28$ & 20 Jun 2013 & 1980 & 1304 & $\mathrm{CC}$ & - & - \\
\hline
\end{tabular}


(a)

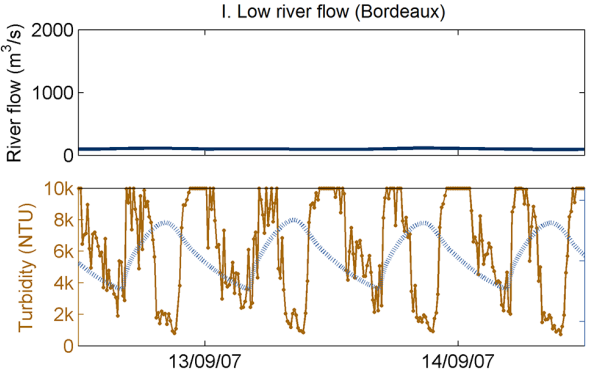

(c)

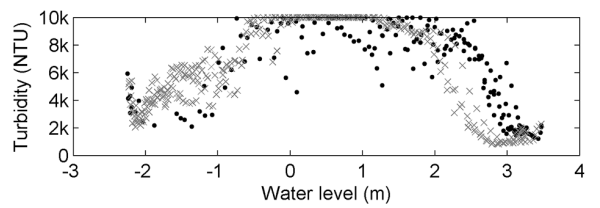

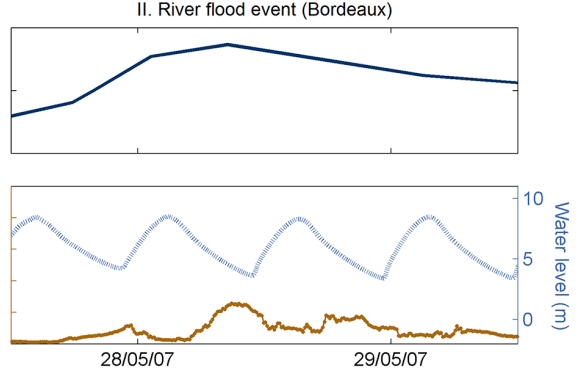

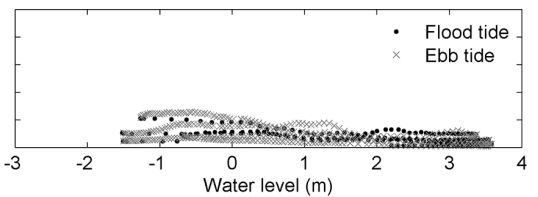

Figure 4. Examples of $48 \mathrm{~h}$ raw data of (a) river flow, and (b) turbidity and water level (dotted lines) at Bordeaux for two contrasted hydrological conditions. The mean time step of river flow is $1 \mathrm{~h}$, while turbidity and water level were recorded every 10 min. (c) Relationships between turbidity and water level records of the middle panels.
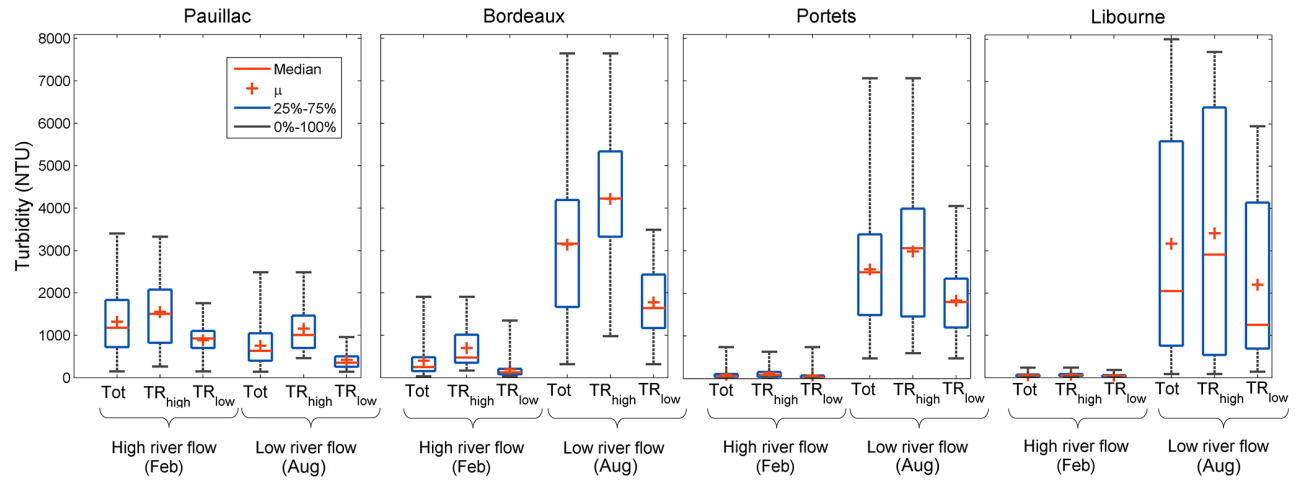

Figure 5. Mean (red cross), median (red bars), percentiles 25-75 (blue bars) and minimum-maximum (black bars) values of tidally averaged turbidity depending on the season (months of February and August) and the tidal range (TR) in each MAGEST station. The minimal, mean and maximal values of river flow in February (2005-2014) are 176, 566 and $2994 \mathrm{~m}^{3} \mathrm{~s}^{-1}$ respectively. These values in August are 56, 103 and $317 \mathrm{~m}^{3} \mathrm{~s}^{-1}$ respectively. High and low tidal ranges correspond to values above the 75th percentile and below the 25 th percentile, respectively, of the entire TR data set of each station.

\subsubsection{Interannual variability}

The observation of the entire data set of tidally averaged turbidity evidences a strong interannual variability in SPM in the fluvial Gironde estuary. Figure 3 makes it possible to appreciate marked differences in the concentration and in the duration of the TMZ for the monitored years at Bordeaux, Portets and Libourne. The maximum turbidity values exceeded 7200 NTU in the years 2010, 2011 and 2012 at Bordeaux and in the years 2010 and 2012 at Libourne. By contrast, during the year 2008 tidal-averaged turbidity was always below 6700 and 4400 NTU at Bordeaux and Libourne respectively. Portets station is less documented: tidal-averaged turbidity maxima ranged between 4730 and 6880 NTU (years 2009 and 2006, respectively). The dura-

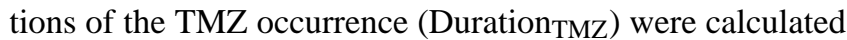
per year as the number of days during which tidal-averaged turbidity is above $1000 \mathrm{NTU}$ (Fig. 6). In general, the TMZ is less present for the more upstream reaches. Annual durations decrease from Bordeaux (varying between 93 and 259 days; years 2013 and 2011, respectively) to Portets (varying between 91 and 171 days; years 2006 and 2008, respectively) and to Libourne (varying between 33 and 143 days; years 2007 and 2011, respectively). The TMZ appeared also during dry winters (striped bars in Fig. 6), as in 2012 (39 days at Bordeaux and 6 days at Libourne).

\section{Discussion}

The presence of TMZ (duration, turbidity level, hibernal occurrence) is more marked and better documented in Bordeaux waters. The following discussion is dedicated to the tidal Garonne. 


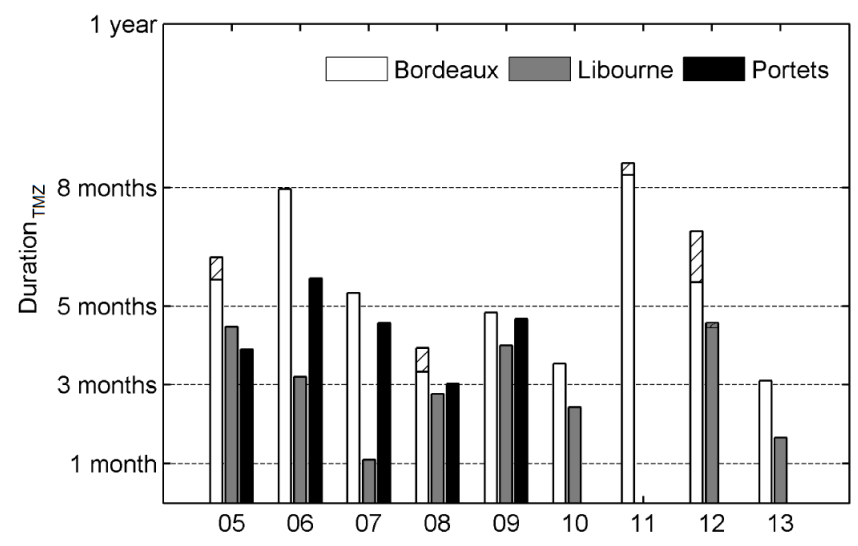

Figure 6. Duration of the TMZ presence per year at the three tidal rivers stations. Striped bars designate the duration of the TMZ when it appears in winter: $17,18,9$ and 39 days respectively in the years 2005, 2008, 2011 and 2012 at Bordeaux; 6 days in the year 2012 at Libourne.

\subsection{Mobile mud downstream flushing rhythm based on sediment dynamics during floods}

River floods expel the TMZ (and its associated mobile mud) from fluvial to middle estuary as shown in Fig. 3. Mitchell et al. (2012) related this downstream flushing to a lack of settling at high slack water during high river discharge. According to Castaing and Allen (1981), the repetition of strong flood events, along with spring tides, favours the flushing of a part of the TMZ toward the sea. Floods also transport eroded sediments from the watershed that contribute to the TMZ. Identifying both processes is important to discuss the role of floods on the sedimentary budget of tidal rivers. The literature proposes hysteresis-based analysis to search for specific patterns of sediment transport in rivers (Williams, 1989; Klein, 1984; López-Tarazón et al., 2009). The relative position of sediment sources within the catchment is analysed through the flow sediment hysteresis shapes (clockwise or counterclockwise). In short, counterclockwise loops correspond to a transport of sediments from upstream distant sources, while clockwise loops occur when the sediment source is the channel itself or adjacent areas. Based on the MAGEST turbidity database, flow sediment hysteresis shapes were systematically analysed for the 26 floods recorded at Bordeaux (13 at Portets; Table 1). Only the values at low tide were used to trace the loops in order to preserve the fluvial signal and to avoid the impact of local resuspension by tidal currents on the levels of turbidity. The succession of hysteresis shapes over several years follows a seasonal pattern in the Garonne tidal river (Table 1, illustrated for the year 2013 in Fig. 7). In the case of Bordeaux:

- The first floods that occur at the end of the low discharge period and expel the TMZ down-estuary show clockwise (C) hysteresis loops (e.g. f3, f8, f11, f24, Ta- ble 1; f24 in Fig. 7). This indicates the advection of resuspended sediments from the close bed and banks. When the TMZ is present in the fluvial section, there is an accretion of sediments that remain after the TMZ downstream flushing. This mud is eroded by river flood.

- Winter and some early spring floods present mixed (M) hysteresis curves, i.e. clockwise loops with a counterclockwise loop around the flood peak (f25 in Fig. 7). Some events show a predominance of the clockwise loop $(\mathrm{M}(\mathrm{C})$, e.g. floods $\mathrm{f} 1, \mathrm{f} 4, \mathrm{f} 17$, Table 1$)$, or of the counterclockwise loop (M(CC), e.g. floods f15, f18, Table 1). This pattern suggests the presence of local sediments, probably remaining from a previous TMZ period, and also the transport of sediment from remote areas. The predominant loop could be interpreted in terms of the proportion of each sediment source.

- Spring floods follow counterclockwise (CC) hysteresis patterns (e.g. floods f2, f7, f10, f28, Table 1; f26, f27, f28 in Fig. 7). This means that sediments are mainly transported from upstream areas; the TMZ-derived mud is expected to be totally expelled.

A similar seasonal evolution of hysteresis also exists at Portets, but it is subtler probably due to its upstream position: the flow sediment curves of the first floods are mixed and counterclockwise loops already appear in winter (Table 1). For example, the flood f1 (31 January 2006) presented a mixed, but predominantly $\mathrm{C}$, loop at Bordeaux indicating dominant local sediments, whereas the simultaneous CC loop at Portets traced a distant origin of sediments. The TMZ-originated mud is less present locally and more quickly expelled in the uppermost section.

Therefore, hysteresis curves are indicators of the presence of mobile mud in tidal rivers, as schematized in Fig. 8, and allow us to discuss its rhythm of downstream flushing for different hydrological conditions and positions along the tidal river axis. During the wet years 2008 and 2009 the mud disappeared from Portets and Bordeaux in the beginning of winter with the first floods. In contrast, mud was only expelled in May during the dry years 2007 and 2012. In the case of the period from January to May 2010, the observation of mixed patterns shows that mobile mud was not completely flushed out (Table 1): this is explained by the absence of major floods until the following upstream migration of the TMZ.

This first detailed study of 10-year continuous turbidity records suggests that deposition of mobile mud also occurs in the tidal Gironde, as already reported in the central estuary (Allen, 1971; Sottolichio and Castaing, 1999). Two-thirds of the floods from 2005 to mid-2014 contributed to the progressive downstream flushing of mobile mud from Bordeaux. As turbidity values associated with floods are significantly lower than those in the TMZ, this demonstrates that floods play a more important role in flushing sediment downstream than in increasing the TMZ concentration. 


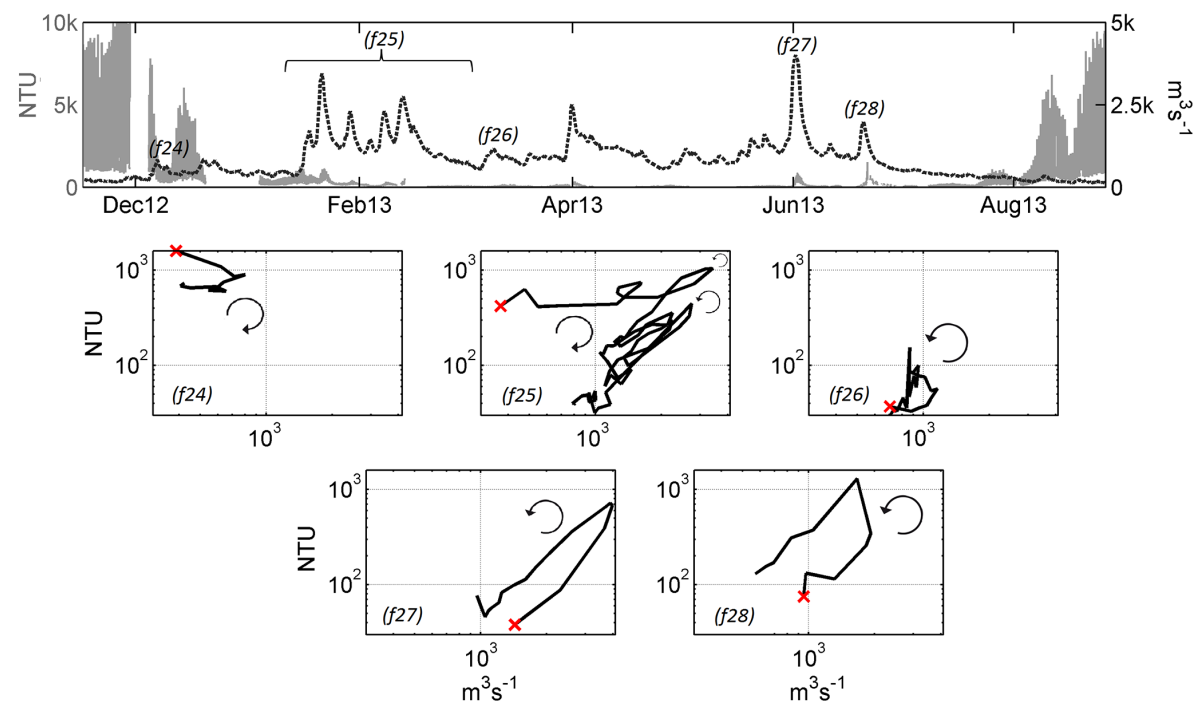

Figure 7. Relationship between Garonne discharge and turbidity at Bordeaux, and corresponding hysteresis patterns for the successive floods occurring since the downstream flushing, in December 2012, and the following upstream migration, in August 2013, of the TMZ; f plus a number refers to the flood events according to Fig. 3 and Table 1.
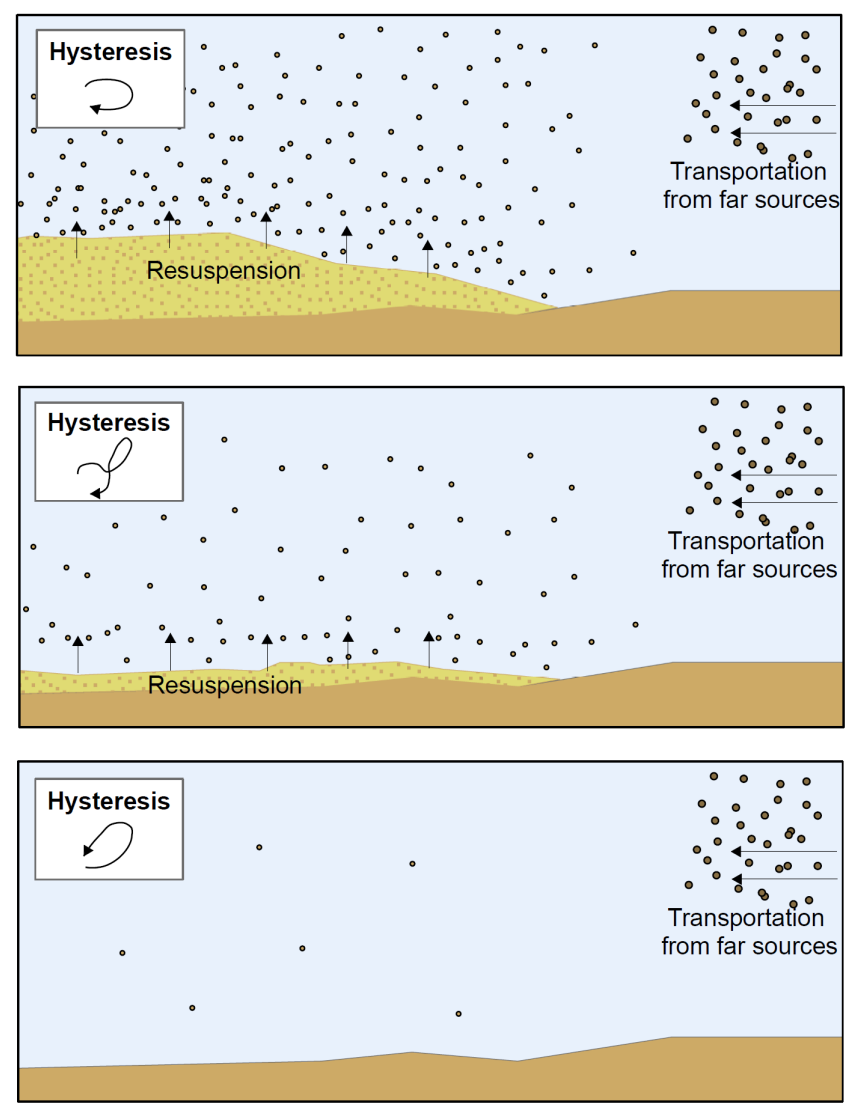

Figure 8. Schematic representation of suspended sediment dynamics in tidal rivers associated with the different types of hysteresis (clockwise, mixed and counterclockwise) during river floods.

\subsection{Occurrence of the TMZ in the tidal river}

The prediction of TMZ location is nowadays a need in the fluvial Gironde estuary and of particular interest to improve regional sediment management. The present work, based on turbidity measurements over the last 10 years, reveals a seasonal occurrence of the TMZ at Portets, $40 \mathrm{~km}$ upstream of Bordeaux. The position of the TMZ along the longitudinal axis depends mainly on the freshwater inflow in major macrotidal European estuaries (e.g. Weser, Seine, Scheldt, Humber, see Mitchell, 2013). To better understand the relationships between turbidity and river flow in the tidal Garonne River, Fig. 9 shows the tidally (A) and daily (B) averaged turbidity as a function of river flow (3-day average). In Pauillac (central estuary) the dependence on river flow is the weakest: turbidity is slightly lower when the TMZ elongates to the upper reaches, but also when floods push suspended sediments seaward. In the tidal Garonne River, turbidity increases with decreasing river flow for discharges lower than about 1000 and $600 \mathrm{~m}^{3} \mathrm{~s}^{-1}$ at Bordeaux and Portets, respectively. At Bordeaux, the maximum turbidity values remain rather constant in the range $50-200 \mathrm{~m}^{3} \mathrm{~s}^{-1}$ because of the saturation of the turbidity sensor. For the highest discharges $\left(>1500 \mathrm{~m}^{3} \mathrm{~s}^{-1}\right)$, turbidity increases up to about $2450 \mathrm{NTU}$ with increasing river flow.

Determining a precise discharge threshold of the TMZ installation per station is tricky, due to the large variability in turbidity, more than 1 order of magnitude at $200 \mathrm{~m}^{3} \mathrm{~s}^{-1}$, partly explained by the tidal range and the locally available sediment stock. During spring tides, current velocities and thus bed shear stress are stronger, promoting sediment resuspension and hence higher turbidity. This process is visi- 
(A)

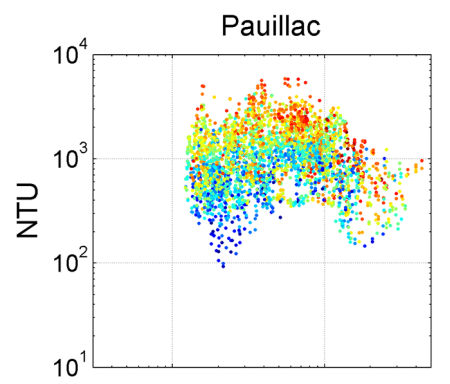

(B)

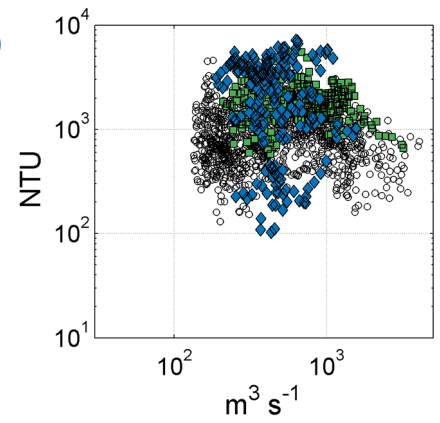

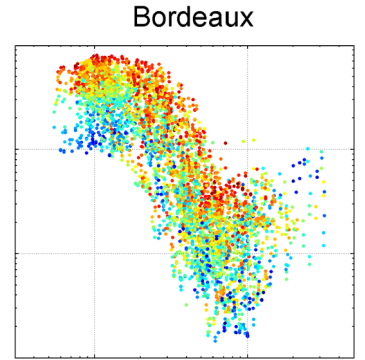
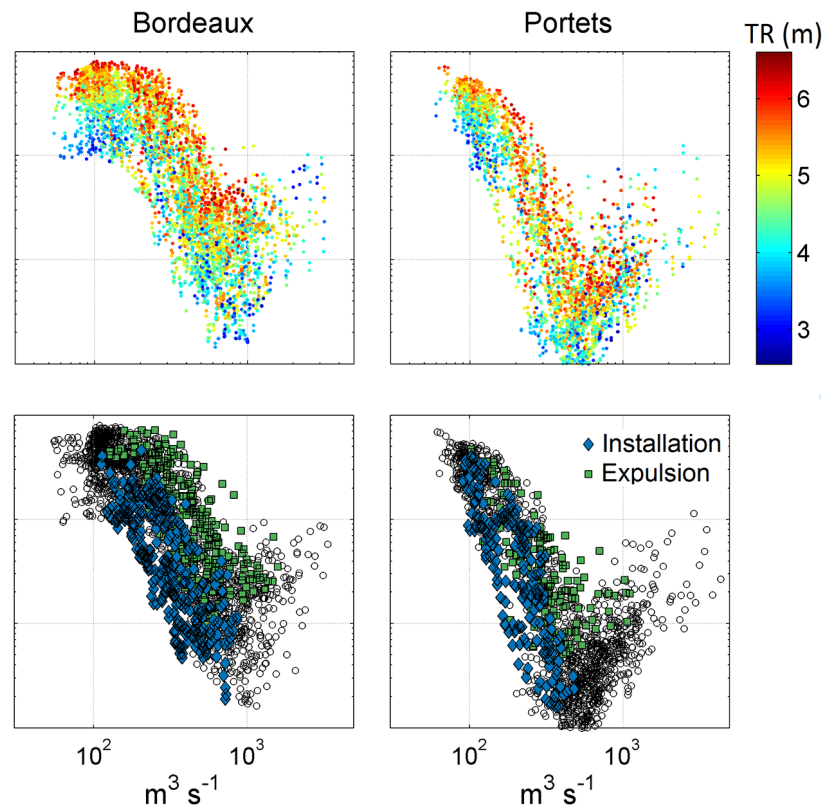

Figure 9. Tidally averaged turbidity (a) and daily averaged turbidity (b) as a function of 3-day averaged river flow for the MAGEST stations of Pauillac, Bordeaux and Portets (log-log representation). (a) Values are classified as a function of tidal range (TR). (b) Values correspond to the periods of installation (blue diamonds) and expulsion (green square) of the TMZ.

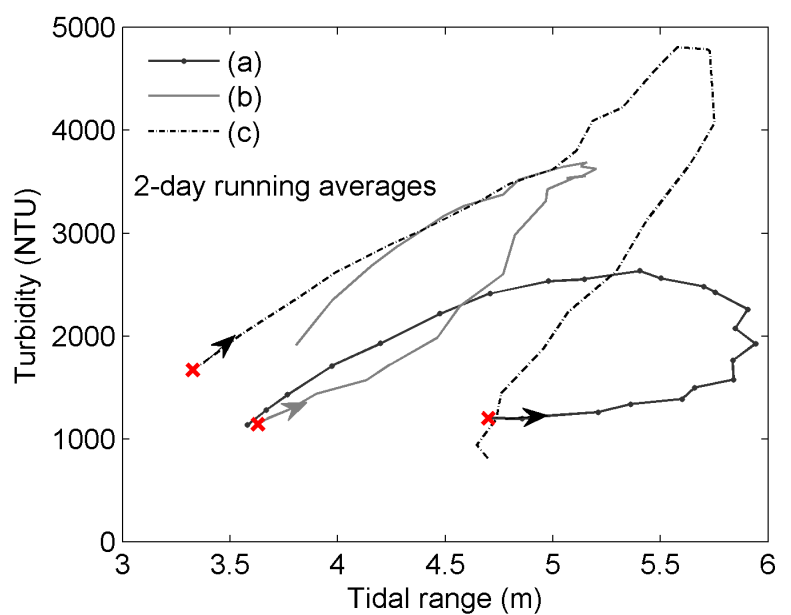

Figure 10. Turbidity as a function of tidal range (2-day running averages) for three neap-spring-neap cycles (see the cycles in Fig. 3d) during a period of (a) installation, (b) presence and (c) expulsion of the TMZ at Bordeaux.

ble and quantifiable in Fig. 9a for different discharges. The dependence is strong when the TMZ is installed in the fluvial estuary at low discharge periods. In contrast, the effect of tidal range is almost negligible during floods, when there are no sediments to resuspend from the river bed, as suggested by Mitchell et al. (2012) for the Thames Estuary, and turbidity is then associated with sediments transported from the watershed. To detail the relationship between these variables, Fig. 10 presents turbidity as a function of tidal range
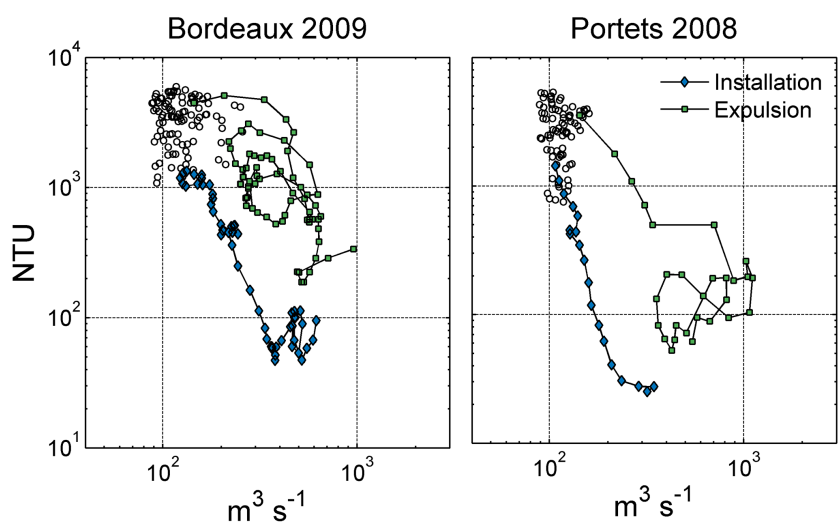

Figure 11. Examples of clockwise discharge/turbidity hysteresis curves during the transition periods of installation and expulsion of the TMZ (see these periods in Fig. 3).

for rising-falling neap-spring cycles during the periods of installation, presence and expulsion of the TMZ at Bordeaux in 2009 (see periods in Fig. 3). During the TMZ installation (a) and when the TMZ is completely installed (b), turbidity was lower during neap-spring tide transition than during the spring-neap tide one. This hysteresis pattern, already observed in other estuaries, is explained by the consolidation of deposited material during neap tides, when current velocities and resuspension are lower (Grabemann et al., 1997; Guézennec et al., 1999; Grabemann and Krause, 2001). During the installation of the TMZ the maximum turbidity oc- 

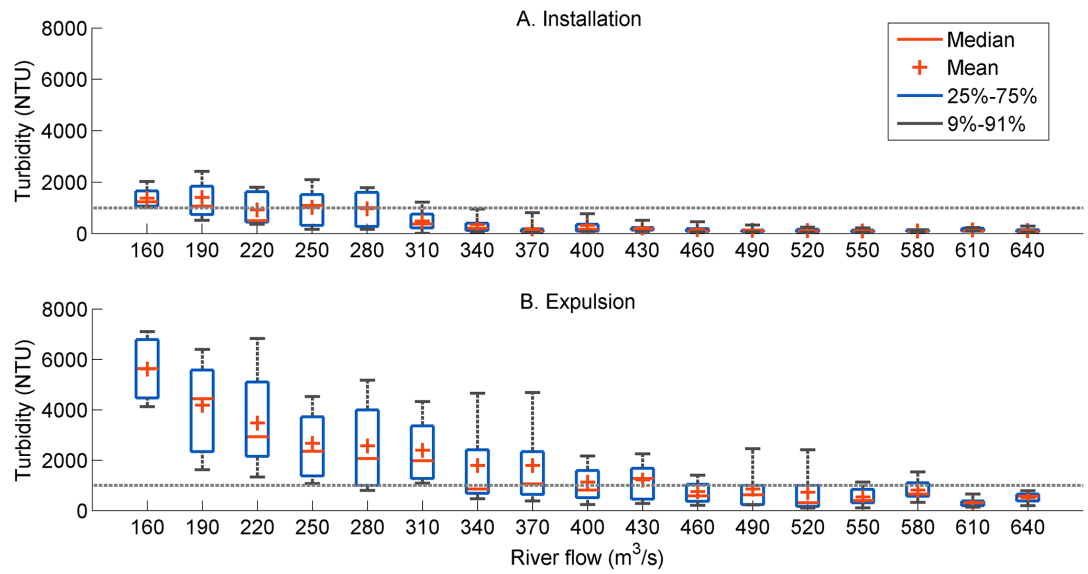

Figure 12. Mean (red cross), median (red bars), 25-75th percentile (blue bars) and 9-91st percentile (black bars) values of tidally averaged turbidity per $30 \mathrm{~m}^{3} \mathrm{~s}^{-1}$ intervals of river flow during the installation and expulsion of the TMZ at Bordeaux.

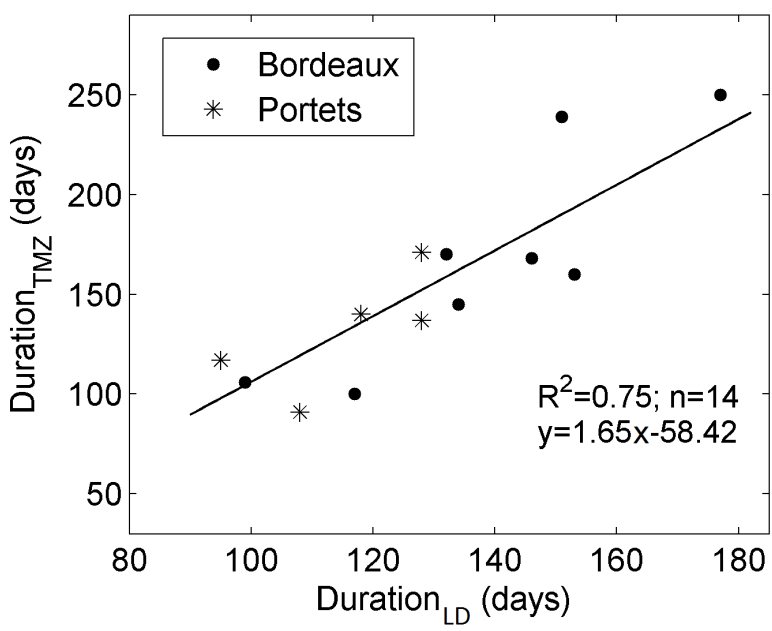

Figure 13. Duration of the TMZ presence as a function of the number of days per year where the river flow was below $250 \mathrm{~m}^{3} \mathrm{~s}^{-1}$ at Bordeaux station and $160 \mathrm{~m}^{3} \mathrm{~s}^{-1}$ at Portets station.

curs 4-5 tidal cycles after the maximum tidal range (Fig. 10, curve a). This is explained by a gradual increase in sediment availability at the riverbed as river discharge decreases, promoting the upstream shift of the TMZ. During the TMZ expulsion period, following river flood, the hysteresis curve is reversed (Fig. 10, curve c), the sediments are progressively resuspended and expelled down estuary and the stock decreases. These behaviours were also found in Portets station.

Differences in turbidity between the periods of decreasing and increasing river flow are also notable in the fluvial estuary (Fig. 9b). In the tidal Garonne, for same discharge intensity, the smallest turbidity values are always associated with the TMZ installation (decreasing discharge) and the highest values during the TMZ expulsion (increasing discharge). This indicates that the discharge turbidity curve follows a clockwise hysteresis over the transitional periods of instal- lation and expulsion of the TMZ (Fig. 11). For example, for a river flow of $500 \mathrm{~m}^{3} \mathrm{~s}^{-1}$, daily averaged turbidity at Bordeaux was 8 to 50 times higher during the falling discharge curve in the year 2009. Such hysteresis was also recorded in the Weser estuary (Grabemann et al., 1997; Grabemann and Krause, 1998), suggesting an association with delays in TMZ movements or with the local sediment inventory. We explain these hysteresis patterns by an accumulation of sediments during the presence of the TMZ that needs large river flow to be expelled. This agrees with the existence a deposition flux of mud remaining in the upper reaches after the passage of the TMZ.

A distinction in turbidity values corresponding to the periods of TMZ installation or expulsion is then necessary to identify the discharge threshold of the TMZ installation in tidal rivers. Figure 12 summarizes the distribution of turbidity values as a function of river flow (intervals of $30 \mathrm{~m}^{3} \mathrm{~s}^{-1}$ ) during the transitional periods of installation and expulsion of the TMZ at Bordeaux station. This allows us to associate a river discharge range with a probability of TMZ installation (as defined by tidal average turbidity $>1000$ NTU, Fig. 12a) or TMZ expulsion (tidal averaged turbidity <1000 NTU, Fig. 12b). The discharges between 200 and $300 \mathrm{~m}^{3} \mathrm{~s}^{-1}$ present the highest potential for promotion of the TMZ installation. The expulsion threshold is less bounded since the intensity and the amount of first floods are variable. Discharges greater than $350 \mathrm{~m}^{3} \mathrm{~s}^{-1}$ promote the TMZ expulsion, and discharges above over $610 \mathrm{~m}^{3} \mathrm{~s}^{-1}$ ensure the complete expulsion.

\subsection{Has the TMZ intensified in the tidal Garonne?}

In the absence of historical turbidity data in tidal rivers, it is difficult to judge the evolution of the TMZ. There are only a few limited available data sets, issued from field campaigns. For example in September 1960, SPM concentrations of sur- 

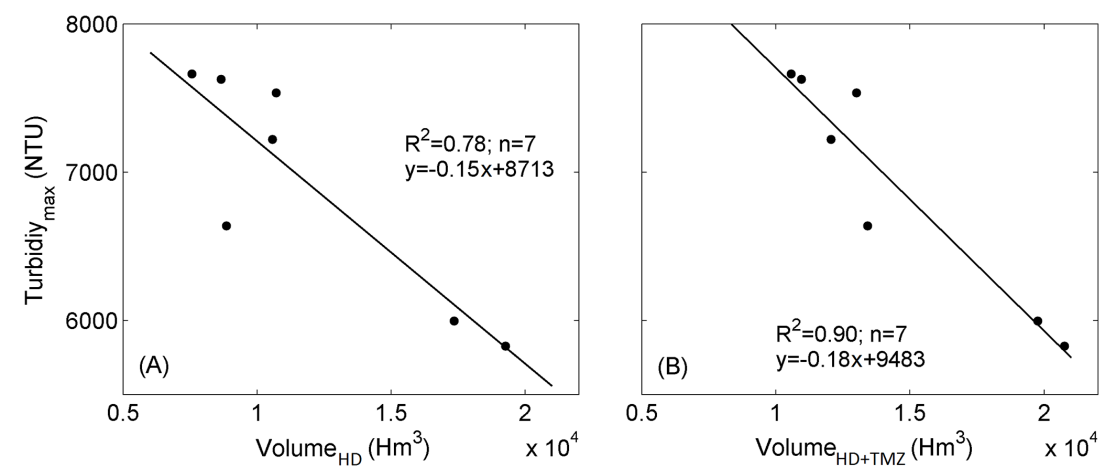

Figure 14. Turbidity maxima of the TMZ as a function of the water volume passed: (a) during the previous wet period and (b) during the previous wet period + the presence of the TMZ. Only Bordeaux is considered as it was not possible to estimate Turbiditymax at Portets due to the number of missing data.

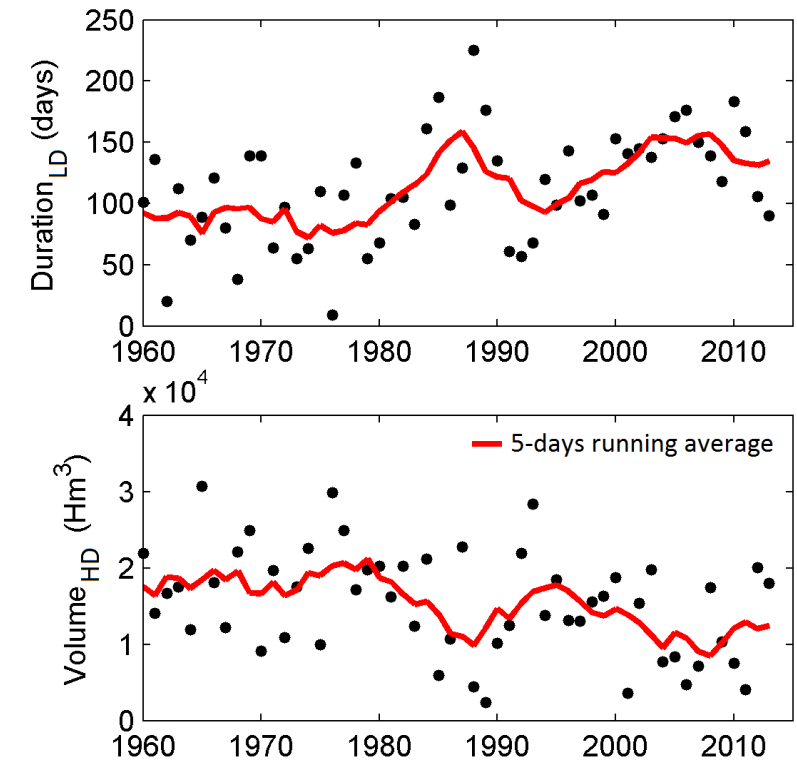

Figure 15. Evolution of the duration of low discharge period (Duration ${ }_{\mathrm{LD}}$ ) and the water volume during high discharge periods

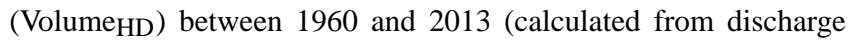
data available on http://www.hydro.eaufrance.fr/); red lines represent 5-day running averages in order to highlight the trends.

face waters at Bordeaux range between $1 \mathrm{gL}^{-1}$ (mean tide) and $2.5 \mathrm{~g} \mathrm{~L}^{-1}$ (spring tide) (Castaing et al., 2006). At Portets, SPM concentration reached $2.5 \mathrm{~g} \mathrm{~L}^{-1}$ just before high tide for spring tide, while at mean and neap tides, SPM concentrations were always below $1 \mathrm{~g} \mathrm{~L}^{-1}$. Romaña (1983) presented quasi-instantaneously turbidity measurements implemented by helicopter along the estuary for 3 days of contrasting hydrological conditions in the years 1981 and 1982. At low water TMZ appeared $10 \mathrm{~km}$ upstream Portets reaching a maximum value of $1.7 \mathrm{~g} \mathrm{~L}^{-1}$. Although these values seem lower than current turbidity trends, the extremely limited measurement periods and the difference in sampling points prevent us from drawing conclusions about a possible TMZ intensification in the tidal river. However, the remarkable dependence of turbidity to river flow in the fluvial section (Fig. 9) suggests that the decreasing trend in river flow in the last decades (Sect. 4.1) may have promoted an upstream intensification of the TMZ.

The 10-year data set of the MAGEST stations of Bordeaux and Portets was used to evaluate the impact of hydrological conditions on TMZ (turbidity level and persistence) in the tidal Garonne. The annual maximum turbidity value (Turbidity $y_{\max }$, as an indicator of turbidity level) and the duration (Duration ${ }_{\mathrm{TMZ}}$ ) of the TMZ were compared to three hydrological characteristics:

1. Duration ${ }_{\mathrm{LD}}$ : the duration of low discharge period, calculated as the number of days per year river flow is below $250 \mathrm{~m}^{3} \mathrm{~s}^{-1}$ at Bordeaux (Fig. 12) and $160 \mathrm{~m}^{3} \mathrm{~s}^{-1}$ at Portets; these values were evaluated as the mean critical river flows above which the TMZ is installed in two stations;

2. $\mathrm{Vol}_{\mathrm{HD}}$ : the river water volume passed during the previous high discharge period, i.e. between the last expulsion and the reinstallation of the TMZ;

3. Vol TMZ: the river water volume passed during the presence of the TMZ at the considered station.

The Duration ${ }_{\mathrm{TMZ}}$ in both stations is well correlated to the Duration $_{\mathrm{LD}}\left(R^{2}=0.75\right)$ as shown in Fig. 13. Years with a long low discharge period like 2011, 2006 or 2007 have a more persistent TMZ than years like 2013 or 2010 characterized by shorter periods of low river flow.

There is also a good correlation between Turbidity $\max _{\max }$ and Volume $_{\mathrm{HD}}\left(R^{2}=0.78\right.$, Fig. 14a). Years with numerous and large floods (like 2008, 2009 and 2013) present a less turbid TMZ. This can be the result of the total downstream flushing of mobile sediment (as seen in Sect. 5.2) and of the further flushing of the previous TMZ (Castaing and Allen, 1981). The Volume $_{\text {LD }}$ is not correlated to Turbidity max $_{\text {. However, }}$ 
the sum of Volume $\mathrm{LD}_{\mathrm{D}}$ and Volume $\mathrm{HD}_{\mathrm{H}}$ improves the correlation $\left(R^{2}=0.90\right)$. This is because the water volume during very wet summers is enough to partly expel the TMZ.

In summary, the duration of the low discharge period mainly determines the TMZ duration, and the freshwater volume during high discharge periods the TMZ concentration. High river flows are efficient in flushing the TMZ in the central estuary, even to the coastal waters, and expel higher quantity of mobile mud, as seen in Sect. 5.2. In order to discuss the potential evolution of the TMZ in the last decades, we calculated the Duration ${ }_{\text {LD }}$ and the Volume HD $_{\text {at Bordeaux }}$ between 1960 and 2013 (Fig. 15). There is a trend in decreasing Volume HD $_{\text {and increasing Duration }}$ LD, especially since the 1980s, which has changed the TMZ characteristics. The decrease in river discharge is attributed to climate change and human activities (Mazzega et al., 2014). For example, in the years 1963 and 1976 the low discharge period lasted respectively only 20 and 9 days, and Volume $\mathrm{HD}$ reached $2.5 \times 10^{4} \mathrm{Hm}^{3}$ in 1969 and 1977 and $3 \times 10^{4} \mathrm{Hm}^{3}$ 1965 and 1976. Considering the relationship between TMZ and hydrology (Figs. 13 and 14), we assume that the TMZ is at present more persistent and turbid than 40-50 years ago. Furthermore, an accumulation effect can favour this intensification. As the TMZ is concentrated in SPM and persistent, the required water volume to expel it increases, promoting the next TMZ to be more pronounced.

According to recent streamflow simulations from 1976 to 2100 based on 22 European river basins, including the Garonne watershed, average discharges are projected to decrease in southern Europe, and extreme events to increase (Alfieri et al., 2015). In this context, the finding of straightforward river-discharge-based indicators of TMZ behaviour should be of great interest for future river basin management plans in the fluvial Garonne.

The effect of river discharge is assumed to be a major factor in the longitudinal shift of the TMZ. However, morphological changes (natural or anthropogenic) may also contribute to the TMZ intensification (Winterwerp and Wang, 2013; De-Jonge et al., 2014), by amplifying tidal asymmetry and hence enhancing trapping of fine sediments, as suggested by Sottolichio et al. (2011). The existence and importance of these changes is not documented yet and will be the subject of future research. The combined effect of changes in topography and in river flow on the TMZ evolution needs be analysed by numerical modelling.

\section{Conclusions}

The high-frequency and long-term turbidity monitoring provides detailed information on suspended sediment dynamics in the fluvial Gironde Estuary over a wide range of timescales and hydrological conditions. Tide, river flow and sediment stock (mobile mud patches) induce large variability on turbidity levels. Suspended sediment dynamics related to tidal cycles (semidiurnal and fortnightly) follows the same cyclic processes in the tidal section, as previously described in the lower estuary (Allen et al., 1977). The TMZ occurrence in the tidal rivers is very sensitive to changes in hydrological conditions. River discharge is a key variable to explain the upstream migration, downstream flushing and concentration of the TMZ and its associated mobile mud. River discharge thresholds promoting the installation and expulsion of the TMZ at Bordeaux have been delimited, 250 and at least $350 \mathrm{~m}^{3} \mathrm{~s}^{-1}$ respectively, showing the need to a higher "water effort" to expel the TMZ. Two hydrological indicators of the TMZ intensity have been defined: the duration of low discharge periods as indicator of the persistence of the TMZ, and water volume passing before and during the presence of the TMZ as indicator of the TMZ turbidity level. Higher water volume contributes to more efficiently move the TMZ and to expel a higher quantity of the remaining mobile mud, resulting in less concentrated TMZ. The existence of mobile mud during and after the TMZ presence is confirmed through turbidity-discharge hysteresis patterns over different scales, which reveal the local or remote location of the sediment source. More particularly, these hysteresis patterns over river floods can serve as an indicator of the rhythm of downstream flushing of mobile mud.

The extrapolation of hydrological conditions suggests an intensification of the TMZ occurrence in the fluvial Gironde during the last decades and could be used to evaluate future scenarios. This can be very useful to water management strategies in order to address the global change impacts as Garonne 2050 (www.garonne2050.fr). The estimate of discharge thresholds of TMZ installation and expulsion is also of great interest to local public authorities. For example, a partner of the MAGEST network, the SMEAG, is in charge of maintaining a minimum discharge level of the Garonne to ensure a water quality favourable to ecosystems (http://www.smeag. fr/plan-de-gestion-detiage-garonne-ariege.html). Their criterion to release water stocks from upstream dams is the level of dissolved oxygen in Bordeaux waters. It appears from this work that the discharge threshold, below $100-110 \mathrm{~m}^{2} \mathrm{~s}^{-1}$, used by the SMEAG is far too low to prevent the installation of the TMZ, and the subsequent problems (dissolved oxygen consumption, pollutant accumulation...).

Finally, this work will be useful to improve the calibration of numerical models coupling hydrodynamics and suspended sediment transport. Numerical simulations will allow evaluate the turbidity in the upper estuary for different hydrological and climate scenarios (naturals and anthropogenic), including the effect of morphological changes.

Acknowledgements. I. Jalón-Rojas thanks the Agence de l'Eau Adour-Garonne (AEAG) and the Aquitane Region for the financial support of her $\mathrm{PhD}$ grant. The MAGEST network is financially supported by the following organizations: AEAG (Agence de l'Eau Adour-Garonne); SMIDDEST (Syndicat MIxte 
pour le Développement Durable de l'ESTuaire de la Gironde); SMEAG (Syndicat Mixte d'Etudes et d'Aménagement de la Garonne); EPIDOR (Etablissement Public Interdépartemental de la Dordogne); EDF; GPMB (Grand Port Maritime de Bordeaux); CUB (Communauté Urbaine de Bordeaux); Conseil Régional Aquitaine; CG-33 (Conseil Général de Gironde); Ifremer; CNRS; Université de Bordeaux. The authors also gratefully acknowledge the support of the OASU (Observatoire Aquitain des Sciences de l'Univers) through the SOLAQUI (Service d'Observation du Littoral AQUItain) programme. MAGEST is a contribution to the CNRS observation programme DYNALIT.

Edited by: A. D. Reeves

\section{References}

Alfieri, L., Burek, P., Feyen, L., and Forzieri, G.: Global warming increases the frequency of river floods in Europe, Hydrol. Earth Syst. Sci., 19, 2247-2260, doi:10.5194/hess-19-22472015, 2015.

Allen, G. P.: Déplacements saisonniers de la lentille de "crème de vase" dans l'estuaire de la Gironde, C. R. Acad. Sc. Paris, 273, 2429-2431, 1971.

Allen, G. P. and Castaing, P.: Suspended sediment transport from the Gironde estuary (France) onto the adjacent continental shelf, Marine Geol., 14, 47-53, 1973.

Allen, G. P., Sauzay, G., and Castaing, P.: Transport and deposition of suspended sediment in the Gironde Estuary, France, in: Estuarine Processes, edited by: Wiley, M., Academic Press, New York, 2 edn., 63-81, 1977.

Allen, G. P., Salomon, J. C., Bassoullet, P., Du Penhoat, Y., and De Grandpré, C.: Effects of tides on mixing and suspended sediment transport in macrotidal estuaries, Sediment. Geol., 26, 6990, 1980.

Bonneton, P., Bonneton, N., Parisot, J.-P., and Castelle, B.: Tidal bore dynamics in funnel-shaped estuaries, J. Geophys. Res., doi:10.1002/2014JC010267, 2015.

Castaing, P. and Allen, G. P.: Mechanisms controlling seaward escape of suspended sediment from the Gironde: A macrotidal estuary in France, Marine Geol., 40, 101-118, 1981.

Castaing, P., Etcheber, H., Sottolichio, A., and Cappe, R.: Evaluation de l'evolution hydrodolique et sedimentaire du système Garonne-Dordogne-Gironde, Tech. rep., Rapport Agence de l'eau Adour-Garonne - Université de Bordeaux, 2006.

Chanson, H., Reungoat, D., Simon, B., and Lubin, P.: Highfrequency turbulence and suspended sediment concentration measurements in the Garonne River tidal bore, Estuarine, Coast. Shelf Sci., 95, 298-306. doi:10.1016/j.ecss.2011.09.012, 2011.

Contreras, E. and Polo, M. J.: Measurement frequency and sampling spatial domains required to characterize turbidity and salinity events in the Guadalquivir estuary (Spain), Nat. Hazards Earth Syst. Sci., 12, 2581-2589, doi:10.5194/nhess-12-25812012, 2012.

De-Jonge, V. N., Schuttelaars, H. M., Van-Beusekom, J. E., Talke, S. A., and De-Swart, H. E.: The influence of channel deepening on estuarine turbidity levels and dynamics, as exemplified by the Ems estuary, Estuarine, Coast. Shelf Sci., 139, 46-59, doi:10.1016/j.ecss.2013.12.030, 2014.
Doxaran, D., Froidefond, J. M., Castaing, P., and Babin, M.: Dynamics of the turbidity maximum zone in a macrotidal estuary (the Gironde, France): Observations from field and MODIS satellite data, Estuarine, Coast. Shelf Sci., 81, 321-332, doi:10.1016/j.ecss.2008.11.013, 2009.

Dyer, K. R.: Fine sediment particle transport in estuaries, in: Physical Process in Estuaries, edited by: Dronkers, J. and van Leussen, W., Springer-Verlag, 427-445, 1988.

Etcheber, H., Schmidt, S., Sottolichio, A., Maneux, E., Chabaux, G., Escalier, J. M., Wennekes, H., Derriennic, H., Schmeltz, M., Quéméner, L., Repecaud, M., Woerther, P., and Castaing, P.: Monitoring water quality in estuarine environments: lessons from the MAGEST monitoring programme in the Gironde fluvial-estuarine system, Hydrol. Earth Syst. Sci., 15, 831-840, doi:10.5194/hess-15-831-2011, 2011.

Fettweis, M., Sas, M., and Monbaliu, J.: Seasonal, Neap-spring and Tidal Variation of Cohesive Sediment Concentration in the Scheldt Estuary, Belgium, Estuarine, Coast. Shelf Sci., 47, 2136, doi:10.1006/ecss.1998.0338, 1998.

Fettweis, M., Monbaliu, J., Baeye, M., Nechad, B., and Van den Eynde, D.: Weather and climate induced spatial variability of surface suspended particulate matter concentration in the North Sea and the English Channel, Methods in Oceanography, 3-4, 25-39, doi:10.1016/j.mio.2012.11.001, 2012.

Fontugne, M. R. and Jouanneau, J.-M.: Modulation of the particulate organic carbon flux to the ocean by a macrotidal estuary: Evidence from measurements of carbon isotopes in organic matter from the Gironde system. Est. Coast. Shelf Sci., 24, 377-387, 1987.

Garel, E., Nunes, S., Neto, J. M., Fernandes, R., Neves, R., Marques, J. C., and Ferreira, O.: The autonomous Simpatico system for real-time continuous water-quality and current velocity monitoring: examples of application in three Portuguese estuaries, Geo-Mar. Lett., 29, 331-341, doi:10.1007/s00367-009-0147-5, 2009.

Grabemann, I. and Krause, G.: Response of the turbidity maximum in the Weser Estuary to pulses in freshwater runoff and to storms, Phys. Est. Coast. Seas, edited by: Dronkers, J. and Scheffers, M., 83-92, 1998.

Grabemann, I. and Krause, G.: On Different Time Scales of Suspended Matter Dynamics in the Weser Estuary, Estuaries, 24, 688-698, 2001.

Grabemann, I., Uncles, R. J., Krause, G., and Stephens, J. A.: Behaviour of Turbidity Maxima in the Tamar (U.K.) and Weser (F.R.G.) Estuaries, Estuarine, Coast. Shelf Sci., 45, 235-246, doi:10.1006/ecss.1996.0178, 1997.

Guézennec, L., Lafite, R., Dupont, J. P., Meyer, R., and Boust, D.: Hydrodynamics of Suspended Particulate Matter in the Tidal Freshwater Zone of a Macrotidal Estuary (The Seine Estuary, France), Estuaries, 22, 717-727, doi:10.2307/1353058, 1999.

Hendrickx, F. and Sauquet, E.: Impact of warming climate on water management for the Ariège River basin (France), Hydrol. Sci. J., 58, 976-993, doi:10.1080/02626667.2013.788790, 2013.

Jay, D. A. and Musiak, J. D.: Particle trapping in estuarine tidal flows, J. Geophys. Res., 99, 20445-20461, 1994.

Klein, M.: Anti closckwise hysteresis in suspended sediment concentration during individual storms: Holbeck Catchment, Yorkshire, England, Catena, 11, 251-257, 1984. 
Lanoux, A., Etcheber, H., Schmidt, S., Sottolichio, A., Chabaud, G., Richard, M., and Abril, G.: Factors contributing to hypoxia in a highly turbid, macrotidal estuary (the Gironde, France), Environ. Sci. Proc. Imp., 15, 585-595, doi:10.1039/c2em30874f, 2013.

López-Tarazón, J. A., Batalla, R. J., Vericat, D., and Francke, T.: Suspended sediment transport in a highly erodible catchment: The River Isábena (Southern Pyrenees), Geomorphology, 109, 210-221, doi:10.1016/j.geomorph.2009.03.003, 2009.

Mazzega, P., Therond, O., Debril, T., March, H., Sibertin-Blanc, C., Lardy, R., and Sant'ana, D.: Critical multi-level governance issues of integrated modelling: An example of low-water management in the Adour-Garonne basin (France), J. Hydrol., 519, 2515-2526, doi:10.1016/j.jhydrol.2014.09.043, 2014.

Mitchell, S.: Turbidity maxima in four macrotidal estuaries, Ocean Coast. Manage., 79, 62-69, doi:10.1016/j.ocecoaman.2012.05.030, 2013.

Mitchell, S., Akesson, L., and Uncles, R.: Observations of turbidity in the Thames Estuary, United Kingdom, Water Environ. J., 26, 511-520. doi:10.1111/j.1747-6593.2012.00311.x, 2012.

Mitchell, S. B. and Uncles, R. J.: Estuarine sediments in macrotidal estuaries: Future research requirements and management challenges, Ocean and Coastal Management, 79, 97-100, doi:10.1016/j.ocecoaman.2012.05.007, 2013.

Pontee, N., Whitehead, P., and Hayes, C.: The effect of freshwater flow on siltation in the Humber Estuary, north east UK, Estuarine, Coast. Shelf Sci., 60, 241-249, doi:10.1016/j.ecss.2004.01.002, 2004.

Romaña, A.: Estuaire de la Gironde. Campagnes "Libellule", Distribution longitudinale des paramètres mesurés et calculés, Tech. rep., Rapport Ifremer, Dépt. Env. Litt. et Gest. du Milieu Marin, 1983.

Saari, H. K., Schmidt, S., Castaing, P., Blanc, G., Sautour, B., Masson, O., and Cochran, J. K.: The particulate 7Be/210Pbxs and $234 \mathrm{Th} / 210 \mathrm{Pbxs}$ activity ratios as tracers for tidal-to seasonal particle dynamics in the Gironde estuary (France): Implications for the budget of particle-associated contaminants, Science of the Total Environment, 408, 4784-4794, doi:10.1016/j.scitotenv.2010.07.017, 2010.

Schmidt, S., Ouamar, L., Cosson, B., Lebleu, P., and Derriennic, H.: Monitoring turbidity as a surrogate of suspended particulate load in the Gironde Estuary: The impact of particle size on concentration estimates, ISOBAY 2014, abstract book, p. 17, 2014.

Schrottke, K., Becker, M., Bartholomä, A., Flemming, B. W., and Hebbeln, D.: Fluid mud dynamics in the Weser estuary turbidity zone tracked by high-resolution side-scan sonar and parametric sub-bottom profiler, Geo-Mar. Lett., 26, 185-198, doi:10.1007/s00367-006-0027-1, 2006.
Schuttelaars, H. M., de Jonge, V. N., and Chernetsky, A.: Improving the predictive power when modelling physical effects of human interventions in estuarine systems, Ocean Coast. Manage., 79, 70-82, doi:10.1016/j.ocecoaman.2012.05.009, 2013.

Sottolichio, A. and Castaing, P.: A synthesis on seasonal dynamics of highly-concentrated structures in the Gironde estuary, Comptes Rendus de l'Academie de Sciences - Serie IIa: Sciences de la Terre et des Planetes, 329, 795-800, doi:10.1016/S12518050(00)88634-6, 1999.

Sottolichio, A., Castaing, P., Etcheber, H., Maneux, E., Schmeltz, M., and Schmidt, S.: Observations of suspended sediment dynamics in a highly turbid macrotidal estuary, derived from continuous monitoring, J. Coast. Res., SI64, 1579-1583, 2011.

StataCorp: Stata Statistical Software: Release 12, 2011.

Talke, S. A., de Swart, H. E., and Schuttelaars, H. M.: Feedback between residual circulations and sediment distribution in highly turbid estuaries: An analytical model, Cont. Shelf Res., 29, 119135, doi:10.1016/j.csr.2007.09.002, 2009.

Uncles, R. J., Easton, A. E., Griffiths, M. L., Harris, C., Howland, R. J. M., King, R. S., Morris, A. W., and Plummer, D. H.: Seasonality of the Turbidity Maximum in the Humber Ouse Estuary, UK, Marine Poll. Bull., 37, 206-215, 1998.

Uncles, R. J., Stephens, J. A., and Smith, R. E.: The dependence of estuarine turbidity on tidal intrusion length, tidal range and residence time, Cont. Shelf Res., 22, 1835-1856, doi:10.1016/S0278-4343(02)00041-9, 2002.

Uncles, R. J., Stephens, J. A., and Law, D. J.: Turbidity maximum in the macrotidal, highly turbid Humber Estuary, UK: Flocs, fluid mud, stationary suspensions and tidal bores, Est. Coast. Shelf Sci., 67, 30-52, doi:10.1016/j.ecss.2005.10.013, 2006.

Uncles, R. J., Stephens, J. A., and Harris, C.: Towards predicting the influence of freshwater abstractions on the hydrodynamics and sediment transport of a small, strongly tidal estuary: The Devonshire Avon, Ocean Coast. Manage., 79, 83-96, doi:10.1016/j.ocecoaman.2012.05.006, 2013.

Williams, G. P.: Sediment concentration versus water discharge during single hydrologic events in rivers, J. Hydrol., 111, 89-106, doi:10.1016/0022-1694(89)90254-0, 1989.

Winterwerp, J. C. and Wang, Z. B.: Man-induced regime shifts in small estuaries - I: theory, Ocean Dynam., 63, 1279-1292, doi:10.1007/s10236-013-0662-9, 2013.

Yang, Y., Li, Y., Sun, Z., and Fan, Y.: Suspended sediment load in the turbidity maximum zone at the Yangtze River Estuary: The trends and causes, J. Geograph. Sci., 24, 129-142, doi:10.1007/s11442-014-1077-3, 2013. 